\title{
The Relationship Between Reporting Occupational Injuries, Job Control, and Safety Citizenship Sub-dimensions of Action
}

Clint Pinion ${ }^{1 *}$, Joshua Reichert, $\mathbf{P E}^{2}$, and Nathaniel Stephens ${ }^{1}$

${ }^{1}$ Department of Environmental Health Science, College of Health Sciences, Eastern Kentucky University, 521 Lancaster Avenue, Dizney 106, Richmond, KY 40475, United States.

${ }^{2}$ Department of Fire Protection and Paramedicine Sciences, College of Justice \& Safety, Eastern Kentucky University, 521 Lancaster Avenue, Ashland 130, Richmond, KY 40475, United States.

Article Details
Article Type: Research Article
Received date: $10^{\text {th }}$ May, 2021
Accepted date: $09^{\text {th } J u n e, ~} 2021$
Published date: $01^{\text {th } J u l y, ~} 2021$
Corresponding Author: Clint Pinion, Jr., DrPH, MA, CIT, RS, Associate Professor Director, Master of Public Health Pro-
gram, Department of Environmental Health Science College of Health Sciences, Eastern Kentucky University, 521 Lancaster
Avenue Dizney 106, Richmond, KY 40475, United States. E-mail: clint.pinion@eku.edu
Citation: Pinion, C., Reichert, J, \& Stephens, N. (2021). The Relationship Between Reporting Occupational Injuries, Job
Control, and Safety Citizenship Sub-dimensions of Action. J Pub Health Issue Pract 5(2): 178. doi: https://doi.org/10.33790/
jphip1100178
Copyright: C2021, This is an open-access article distributed under the terms of the Creative Commons Attribution License
4.0, which permits unrestricted use, distribution, and reproduction in any medium, provided the original author and source
are credited.

\section{Abstract}

More than five thousand workers lost their lives in 2018 due to occupational incidents. Research suggests that increased job control and safety citizenship can help mitigate occupational incidents. This study aims to answer the following research question: Does a relationship exist between the behavior of reporting occupational injuries and both job control and safety citizenship? This exploratory cross-sectional study used an employee perception questionnaire to examine the behavior of reporting occupational injuries, employee job control, and six safety citizenship sub-dimensions of action (i.e. stewardship, civic virtue, whistleblowing, initiating safety-related change, voice, and helping) at two companies in the Midwestern region of the United States. The survey consisted of 34 items and used a 5-point Likert Scale to quantify the data gathered along with other demographic variables. An ordinal logistic regression analysis to investigate the relationship between the behavior of reporting occupational injuries, job control, and the six sub-dimensions of safety citizenship was conducted. Results indicate that job control $\left(\mathrm{X}^{2}=8.512, \mathrm{df}=1, \mathrm{p}<0.05\right)$ and whistleblowing $\left(\mathrm{X}^{2}=4.836, \mathrm{df}\right.$ $=1, \mathrm{p}<0.05)$ predict the behavior of occupational injury reporting.

Keywords: safety citizenship; occupational injuries; and job control.

\section{Introduction and Background}

Hofman and colleagues [1] note that significant improvements to safety have occurred in workplaces across the United States over the past century. Even with noted improvements, more than five thousand workers lost their lives in 2018 due to occupational incidents [2]. Employers develop policies, procedures, and programs aimed to mitigate occupational injuries, illnesses, and fatalities [3]. Such implementation can reduce the severity of work place injuries, protect employees, and assist the employer in attaining regulatory safety compliance. Griffin and Neal [4] define safety compliance as, "the core safety activities that need to be carried out by individuals to maintain workplace safety" (p.349). Ensuring safety compliance at a workplace does not negate occupational injuries, illnesses, and fatalities. In fact, employers often implement leading indicator programs, which include analyses of workplace events, conditions or measures, to predict and prevent future occupational incidents. The consensus among safety professionals is that safety compliance alone will not halt occupational incidents.

Leading indicator programs often target an increase in safety participation to focus more attention on a company's safety policies, procedures, and programs [5]. Griffin and Neal [4] define safety participation as discretionary activities that are not required as part of the employee's job tasks. These activities, which some researchers refer to as safety citizenship behaviors, assist employers and employees in facilitating and improving workplace safety [6].Safety Citizenship includes, "discretionary and prosocial employee activities that are essential for managing risk in safety critical industries" [7], (p.190). Hoffman and colleagues [8] provide the following examples of safety citizenship behaviors: improving workplace safety through providing suggestions for organization safety change; participating in safety activities beyond mere safety compliance requirements defined in a job task; championing workplace safety programs and policies; and assisting coworkers through coaching and exemplifying proper safety behaviors. Safety participation is more effective in reducing occupational injuries, illnesses, and incidents than safety compliance activities $[9,10]$.

\section{Challenge versus Affiliative Safety Citizenship}

Curcuruto and colleagues [7] present challenge v. affiliative safety citizenship. Affiliative safety citizenship includes behaviors, which are cooperative and interpersonal and aimed at strengthening the overall safety socialization and status quo of a workplace [11]. Affiliative safety citizenship is important when trying to predict micro-accidents and accidents lacking injuries [12]. Challenge-based safety citizenship includes proactive behaviors, which will lead to improvements or change to the existing safety systems at a workplace. Challenge or proactive behaviors are important in predicting losttime injuries and the frequency of near-miss incidents.

Affiliative citizenship is defined by prosocial behaviors and includes concepts such as helping (i.e. employees help coworkers complete their safety responsibilities), civic virtue (i.e. employees engage in non-mandatory safety meetings and programs), whistleblowing (i.e. employees report coworkers for violating safety policies and procedures), and stewardship (i.e. employees protect coworkers from at-risk situations). Challenge safety citizenship is defined by proactive behaviors and includes concepts such as safety voice 
(i.e. employees promote workplace safety activities) and safety related change (i.e. employees initiate change to improve workplace safety) [8]. The extent to which an employee has defined safety as part of their work role helps predict how likely they are to engage in the affiliative type of safety citizenship. The more engrained safety is in an employee's role definition, the more likely they are to participate in affiliative citizenship.

Curcuruto and colleagues [7] note that safety behaviors are either avoidance or approach in motivation. Meaning that some behaviors lead to safety socialization (i.e. process by which employees observe their colleagues to learn acceptable safety behaviors) or safety system implementation (e.g., behavior based observation program launched at the worksite). These approach behaviors are promotional, as they focus on the positive aspects of safety, and rely upon citizenship concepts, such as voice, helping, and initiative. Protection based motivation aims to avoid the negative implications of safety incidents, such as loss-time from work, injuries, illnesses, or fatalities. Citizenship concepts, such as stewardship and whistleblowing, would be associated with avoidance motivation.

Research suggests that increases in workplace safety citizenship is associated with improvements in safety performance (i.e. safety compliance is met) $[10,13]$. Employees report experiencing fewer occupational incidents when they self-report higher safetyparticipation and job control (i.e. job autonomy). Clarke [9] suggests that safety citizenship can help prevent property damage, minor injuries, serious injuries, and fatalities. Curcuruto and colleagues [12] offer that safety performance outcomes are influenced by different safety behaviors. Non-injury occupational incidents and micro-accidents (i.e. injuries requiring medical attention but no time away from work) can be predicted by prosocial behaviors. Prosocial behaviors are team-oriented, focused on helping to instruct coworkers on safety expectations, and places emphasis on monitoring co-worker safety behaviors [12]. Research suggests that a negative correlation exists between prosocial behaviors and micro-accidents and noninjury occupational incidents. A reduction in micro accidents and non-injury occupational incidents occurs when prosocial behaviors rise in prevalence at a workplace.

Proactive behaviors are more important in predicting lost-time occupational injuries and near-miss incidents [12]. Proactive behaviors may include voicing concern over organizational safety policies, procedures or programs through completing safety climate surveys. The ultimate goal of proactive behaviors is to improve workplace safety conditions through identification and mitigation of workplace hazards. A lack of proactive safety participation, ultimately, can be deemed an antecedent of safety violations $[10,14]$ and lost-time, occupational injuries and fatalities [12].

\section{Job Control and Workplace Injuries}

Employees who participate in safety initiatives are more likely to maintain compliance with safety regulations and policies [14]. The likelihood of employees participating in safety activities is associated with how safety is defined in their job role. Employees viewing safety as part of their job are prone to have more evolved definitions of their safety citizenship role [14] and are more likely to engage in safety activities. Turner and colleagues [15] concur with this notion and add that job control is positively related to safety compliance. Job control is defined as an, "employees capacity to control work tasks, work environment, and work task outcomes" [3] , (p.71). Safety-related situational constraints predict workplace injury occurrence and severity. The effect is buffered by job control [16]. Thus, employees can prevent injuries or minimize the severity of injuries by having increased job control. Job control allows the employee to select when and how to expend their cognitive resources and affects their perception of management's commitment to employee safety. Increased job control is associated with positive safety citizenship and improved employee perception of management's commitment to safety [3].

\section{Current Study}

To date, studies have not examined the relationship between injury reporting behaviors of employees, job control, and the six subdimensions of action of safety citizenship in the distilling industry. Such a deficit in literature is surprising, given the positive connection established between: (1) increased safety citizenship and fewer occupational injuries and fatalities; and (2) increased job control and improved safety citizenship. This study aims to answer the following research question: Does a relationship exist between the behavior of reporting occupational injuries and both self-perceived job control and safety citizenship? This study uses a self-report questionnaire to:

1. Assess the relationship between the behavior of occupational injury reporting among employees working in the distilling industry and their self-perceived job control and six subdimensions of action of safety citizenship.

\section{Materials and Methods}

This exploratory cross-sectional study used an employee perception questionnaire to examine self-reported perceptions of occupational injury reporting behaviors, employee job control and safety citizenship at two distilling companies in the Midwestern region of the United States. The companies' work primarily consisted of construction consulting and distilling/bottling. The survey consisted of 34 items and used a 5-point Likert Scale to quantify the data gathered along with other demographic variables. Survey items used to measure job control were based upon those used by Pinion et al. [3] (see Table 1). To measure safety citizenship, a modified version of the scale noted in Hoffman and Morgeson [8] was used (see Table 1). One question was added to the questionnaire to determine if employees report occupational injuries. Employees answered each survey item on a 5-point Likert Scale, (1) Strongly Disagree, (2) Disagree, (3) Neutral, (4) Agree, and (5) Strongly Agree. Demographic information collected included: (a) age, (b) sex, (c) region of origin, (d) education level, (e) position at company, (f) years in industry, (g) years worked for current company, and (h) different locations worked at for company. Age was divided into four categories, (1) $\leq 24$, (2) $25-34$, (3) $35-49$, and (4) $>50$. Region of origin options were: (1) Canada, (2) United States, (3) Central America, (4) South America, (5) Africa, (6) Western Europe, (7) Eastern Europe, (8) Asian Pacific, (9) Australia, and (10) Mexico. Education Level was divided into 5 options; (1) Some High School, (2) High School or GED Diploma, (3) Some College, (4) College Degree, and (5) Graduate Degree. Position was broken down into 5 options; (1) Laborer/Craftworker, (2) Foreman, (3) Supervisor, (4) Technical/Office Support, and (5) Senior Management. Finally, years in industry, years for current company, and number of locations worked all had the same options; (1) $<1$, (2) $1-5$, (3) $6-10$, (4) $11-15$, and $(5) \geq 16$.

\begin{tabular}{|l|}
\hline Job control \\
\hline Employees are routinely involved in the development of safe work procedures \\
\hline Employees have influence over the variety of tasks they perform \\
\hline Employees influence the policies, procedures, and performance concerning their work \\
\hline Employees have influence over the availability of supplies and equipment they need to do their work \\
\hline Employees are properly trained by management in the use of writing safe work procedures \\
\hline Employees have influence over the amount of work they do \\
\hline
\end{tabular}

Table 1 . to be cont... 


\begin{tabular}{|c|c|}
\hline Employees have influence over the training of other employees in thei & unit \\
\hline Employees have influence over the quality of work that they do & \\
\hline Employees have influence over the decisions as to when things will be & lone in their work unit \\
\hline In general, employees have influence over their work and work related & actors \\
\hline Employees have influence over the order in which they perform tasks & work \\
\hline Employees have influence over the pace of their work & \\
\hline Employees have influence over the decisions concerning which indivic & als they work with \\
\hline Employees have influence over the hours or schedule that they work & \\
\hline Employees have influence over the availability of materials they need & do their work \\
\hline Employees have influence on when they work ahead and take short res & breaks during work hours \\
\hline Safety citizenship & \\
\hline Helping & \\
\hline Employees volunteer for safety committees & \\
\hline Employees help teach safety procedures to new team members. & \\
\hline Employees assist others to make sure they perform their work safely. & \\
\hline Voice & \\
\hline Employees encourage others to get involved with safety issues. & \\
\hline Employees make safety-related recommendations about work activitie & \\
\hline Employees express opinions on safety matters even if others disagree. & \\
\hline Stewardship & \\
\hline Employees protect fellow team members from safety hazards. & \\
\hline Employees go out of their way to look out for the safety of other team & nembers. \\
\hline Employees take action to protect other team members from risky situa & ons. \\
\hline Whistleblowing & \\
\hline Employees explain to other team members that they will report safety & iolations. \\
\hline Employees tell other team members to follow safe working procedures & \\
\hline Employees monitor new team members to ensure they are performing & ork safely. \\
\hline Civic Virtue & \\
\hline Employees attend safety meetings. & \\
\hline Employees attend non-mandatory safety meetings. & \\
\hline Employees stay informed of changes in safety policies and procedures & \\
\hline Initiating Safety-related Change & \\
\hline Employees try to improve safety procedures. & \\
\hline Employees try to change the way a job is done to make it safer. & \\
\hline Employees try to change policies and procedures to make them safer. & \\
\hline
\end{tabular}

Table 1. Job control and safety citizenship survey items

\section{Participant Inclusion Criteria}

Inclusion criteria for this study were: (1) individual was employed with one of the two participating companies; (2) individual was able to provide verbal informed consent after listening to the principal investigator read an invitation to take part in the study; (3) individual was able to read and comprehend survey instrument, which was written in English; and (4) individual completed all sections of the survey instrument.

\section{Recruitment and Consent}

Employees working at three separate facilities of the two companies who met the inclusion criteria were invited by the principal investigator to participate in this study. The survey instrument was administered at a time most convenient to the majority of employees. The Principal Investigator read an invitation to take part in the study and only individuals providing verbal consent were given the paper survey instrument to complete.

J Pub Health Issue Pract

Volume 5. 2021. 178

\section{Hypothesis Testing}

Scores for the behavior of reporting occupational injuries (OIS), job control (JCS), and six aspects of safety citizenship (i.e. stewardship [IV2], civic virtue [IV3], whistleblowing [IV4], initiating safetyrelated change [IV5], voice [IV6], and helping [IV7]) were calculated for each participant. Participants rated each question listed in Table 1 between 1 and 5. The highest point total resulting in a total of 5 for OIS, 80 for JCS, and 90 for SCS. The OIS, JCS, and SCS was a summation of scores assigned to each item, divided by the total points possible, expressed as a percent. An ordinal logistic regression analysis to investigate the relationship between the behavior of reporting occupational injuries, job control, and the six sub-dimensions of safety citizenship was conducted. The predictor variables were tested a priori to verify there was no violation of multicollinearity. 


\section{Results}

\section{Response Rate}

A total of 198 employees were invited to take part in this study. The response rate for this study was $77 \%$ or $n=152$. The 152 completed surveys were included in statistical analyses.

\section{Participant Demographics}

The study participants were aged as follows: $8 \%(n=12)$ were 24 years of age or younger, $22 \%(n=34)$ were between the ages of 25 and $34,36 \%(n=54)$ were between the ages of 35 and 49 , and $34 \%$ $(n=52)$ were 50 years of age or older. The study population was overwhelmingly male $(87 \%, \mathrm{n}=132)$ and from the United States $(97 \%, n=147)$. The education of the participants was as follows:
$3 \%(\mathrm{n}=5)$ completed some high school, 52\% $(\mathrm{n}=79)$ completed high school or a GED diploma, $31 \%(\mathrm{n}=47)$ completed some college, $14 \%$ $(\mathrm{n}=21)$ completed a college degree. The majority of participants $(74 \%, n=113)$ identified as laborers or craft workers.

\section{Hypothesis Testing Results}

\section{Internal Consistency Reliability}

Due to the nature of Likert scale surveys, the internal consistency of the responses was conducted using the Cronbach Alpha. The first Cronbach Alpha was found based on the questions related to Job Control. The mean scores and standard deviation of each of the 16 questions can be found in Table 2. Overall, an acceptable level of internal consistency from the responses focused around the category of Job Control was found $(\mathrm{a}=0.896)$.

\begin{tabular}{|c|c|c|c|}
\hline Question & Mean & S.D. & $\begin{array}{l}\text { Cronbach } \\
\text { Alpha }\end{array}$ \\
\hline $\begin{array}{l}\text { Employees are routinely involved in the } \\
\text { development of safe work procedures }\end{array}$ & 3.61 & 0.806 & \multirow[t]{16}{*}{0.896} \\
\hline $\begin{array}{l}\text { Employees have influence over the variety } \\
\text { of tasks they perform }\end{array}$ & 3.70 & 0.905 & \\
\hline $\begin{array}{l}\text { Employees influence the policies, } \\
\text { procedures, and performance concerning } \\
\text { their work }\end{array}$ & 3.66 & 0.935 & \\
\hline $\begin{array}{l}\text { Employees have influence over the } \\
\text { availability of supplies and equipment they } \\
\text { need to do their work }\end{array}$ & 3.64 & 0.916 & \\
\hline $\begin{array}{l}\text { Employees are properly trained by } \\
\text { management in the use of writing safe work } \\
\text { procedures }\end{array}$ & 3.36 & 0.994 & \\
\hline $\begin{array}{l}\text { Employees have influence over the amount } \\
\text { of work they do }\end{array}$ & 3.30 & 1.091 & \\
\hline $\begin{array}{l}\text { Employees have influence over the training } \\
\text { of other employees in their unit }\end{array}$ & 3.51 & 0.891 & \\
\hline $\begin{array}{l}\text { Employees have influence over the quality } \\
\text { of work that they do }\end{array}$ & 3.96 & 0.754 & \\
\hline $\begin{array}{l}\text { Employees have influence over the decisions } \\
\text { as to when things will be done in their work } \\
\text { unit }\end{array}$ & 3.31 & 0.951 & \\
\hline $\begin{array}{l}\text { In general, employees have influence over } \\
\text { their work and work-related factors }\end{array}$ & 3.66 & 0.847 & \\
\hline $\begin{array}{l}\text { Employees have influence over the order in } \\
\text { which they perform tasks at work }\end{array}$ & 3.51 & 0.921 & \\
\hline $\begin{array}{l}\text { Employees have influence over the pace of } \\
\text { their work }\end{array}$ & 3.51 & 1.023 & \\
\hline $\begin{array}{l}\text { Employees have influence over the decisions } \\
\text { concerning which individuals they work } \\
\text { with }\end{array}$ & 3.03 & 1.054 & \\
\hline $\begin{array}{l}\text { Employees have influence over the hours or } \\
\text { schedule that they work }\end{array}$ & 2.70 & 1.206 & \\
\hline $\begin{array}{l}\text { Employees have influence over the } \\
\text { availability of materials they need to do their } \\
\text { work }\end{array}$ & 3.49 & 0.906 & \\
\hline $\begin{array}{l}\text { Employees have influence on when they } \\
\text { work ahead and take short rest breaks during } \\
\text { work hours }\end{array}$ & 3.36 & 1.038 & \\
\hline
\end{tabular}

Table 2. Internal consistency of job control survey items 
The second internal consistency test conducted was focused on the survey questions in the category of Safety Citizenship. Within Safety Citizenship, the survey questions were divided in to 6 subcategories; helping, voice, stewardship, whistleblowing, civic virtue, and initiating safety-related change. Table 3 notes the mean scores and standard deviations for each safety citizenship survey question and the Cronbach Alpha found for each of the six subdimensions of safety citizenship. While a common acceptable level of a Cronbach Alpha is 0.7, it has also been found to be acceptable in areas as low as 0.4 (Taber, 2018). Every subcategory including; helping ( $\alpha=0.587)$, voice ( $\alpha=0.665)$, stewardship ( $\alpha=0.723$ ), whistleblowing ( $\mathrm{a}=0.715)$, civic virtue $(\alpha=0.576)$, and initiating safety-related change $(\alpha=0.610)$ all demonstrated an acceptable level of internal consistency. A test of internal consistency was also found for the category of Safety Citizenship using all 18 questions (combining all subcategories) and is also determined to be at an acceptable level $(\alpha=0.910)$

\begin{tabular}{|c|c|c|c|c|c|}
\hline Category & Question & Mean & S.D. & $\begin{array}{l}\text { Cronbach } \\
\text { Alpha }\end{array}$ & $\begin{array}{l}\text { Cronbach } \\
\text { Alpha }\end{array}$ \\
\hline \multirow[t]{3}{*}{ Helping } & $\begin{array}{l}\text { Employees volunteer for safety } \\
\text { committees }\end{array}$ & 3.43 & 0.851 & \multirow[t]{3}{*}{0.587} & \multirow[t]{18}{*}{0.910} \\
\hline & $\begin{array}{l}\text { Employees help teach safety } \\
\text { procedures to new team members. }\end{array}$ & 3.81 & 0.812 & & \\
\hline & $\begin{array}{l}\text { Employees assist others to make } \\
\text { sure they perform their work safely. }\end{array}$ & 3.78 & 0.799 & & \\
\hline \multirow[t]{3}{*}{ Voice } & $\begin{array}{l}\text { Employees encourage others to get } \\
\text { involved with safety issues. }\end{array}$ & 3.43 & 0.835 & \multirow[t]{3}{*}{0.665} & \\
\hline & $\begin{array}{l}\text { Employees make safety-related } \\
\text { recommendations about work } \\
\text { activities. }\end{array}$ & 3.89 & 0.676 & & \\
\hline & $\begin{array}{l}\text { Employees express opinions } \\
\text { on safety matters even if others } \\
\text { disagree. }\end{array}$ & 3.84 & 0.732 & & \\
\hline \multirow[t]{3}{*}{ Stewardship } & $\begin{array}{l}\text { Employees protect fellow team } \\
\text { members from safety hazards. }\end{array}$ & 4.02 & 0.723 & \multirow[t]{3}{*}{0.723} & \\
\hline & $\begin{array}{l}\text { Employees go out of their way to } \\
\text { look out for the safety of other team } \\
\text { members. }\end{array}$ & 3.78 & 0.845 & & \\
\hline & $\begin{array}{l}\text { Employees take action to protect } \\
\text { other team members from risky } \\
\text { situations. }\end{array}$ & 3.97 & 0.695 & & \\
\hline \multirow[t]{3}{*}{ Whistleblowing } & $\begin{array}{l}\text { Employees explain to other team } \\
\text { members that they will report safety } \\
\text { violations. }\end{array}$ & 3.49 & 0.869 & \multirow[t]{3}{*}{0.715} & \\
\hline & $\begin{array}{l}\text { Employees tell other team members } \\
\text { to follow safe working procedures. }\end{array}$ & 3.61 & 0.781 & & \\
\hline & $\begin{array}{l}\text { Employees monitor new team } \\
\text { members to ensure they are } \\
\text { performing work safely. }\end{array}$ & 3.73 & 0.906 & & \\
\hline \multirow[t]{3}{*}{ Civic Virtue } & Employees attend safety meetings. & 3.77 & 0.888 & \multirow[t]{3}{*}{0.576} & \\
\hline & $\begin{array}{l}\text { Employees attend non-mandatory } \\
\text { safety meetings. }\end{array}$ & 2.88 & 0.972 & & \\
\hline & $\begin{array}{l}\text { Employees stay informed of } \\
\text { changes in safety policies and } \\
\text { procedures. }\end{array}$ & 3.39 & 0.984 & & \\
\hline \multirow[t]{3}{*}{$\begin{array}{l}\text { Initiating Safety- } \\
\text { Related Change }\end{array}$} & $\begin{array}{l}\text { Employees try to improve safety } \\
\text { procedures. }\end{array}$ & 3.85 & 0.795 & \multirow[t]{3}{*}{0.610} & \\
\hline & $\begin{array}{l}\text { Employees try to change the way a } \\
\text { job is done to make it safer. }\end{array}$ & 3.88 & 0.783 & & \\
\hline & $\begin{array}{l}\text { Employees try to change policies } \\
\text { and procedures to make them safer. }\end{array}$ & 3.47 & 0.913 & & \\
\hline
\end{tabular}

Table 3. Internal consistency of safety citizenship survey items 


\section{Ordinal Regression Analysis}

The first step in the ordinal regression analysis is to compare the intercept only model with the new model that contains the independent variables. The model fitness information for both models is provided as $2 \log$ likelihood values. Table 4 presents the findings related to the fitness of both models.

\begin{tabular}{|l|l|l|l|l|}
\hline Model & $\mathbf{- 2}$ Log Likelihood & Chi-Square & df & Sig. \\
\hline Intercept Only & 295.999 & & & \\
\hline Final & 247.695 & 48.304 & 7 & .000 \\
\hline
\end{tabular}

Table 4. Model fitting

Table 4 shows the results of this analysis comparing the intercept only model and the new model that includes the independent variables. The new model, which includes the independent variables of this study, shows a statistically significant chi-square value $\left(\mathrm{X}^{2}=\right.$ $295.999-247.695=48.304, \mathrm{df}=7, \mathrm{p}<0.05$ ). This demonstrates that the independent variables used in this analysis do have a relationship with the dependent variable. A goodness-of-fit test was also conducted to determine if the observed data is a good fit with the fitted new model. For this test, a Pearson and Deviance goodnessof-fit test were conducted. The results of these tests can be seen in Table 5 .
As shown in Table 5, the Pearson's chi-square values $\left(\mathrm{X}^{2}=\right.$ $287.010, \mathrm{df}=287, \mathrm{p}>0.05)$ and the deviance chi-square values $\left(\mathrm{X}^{2}=\right.$ $247.695, \mathrm{df}=287, \mathrm{p}>0.05$ ) were not significant. With neither being significant, this fails to reject the null hypothesis. The supports that the observed data has a good fit with the new model.

A Wald test was conducted to determine if the independent variables were significant. In Table 6 , each independent variable is listed. Table 6 provides the estimated error and standard deviation of each independent variable. Further, the table provides the Wald Chisquare value (estimate/std. error)2. Each Wald statistic is measured with 1 degree of freedom and statistical significance is found.

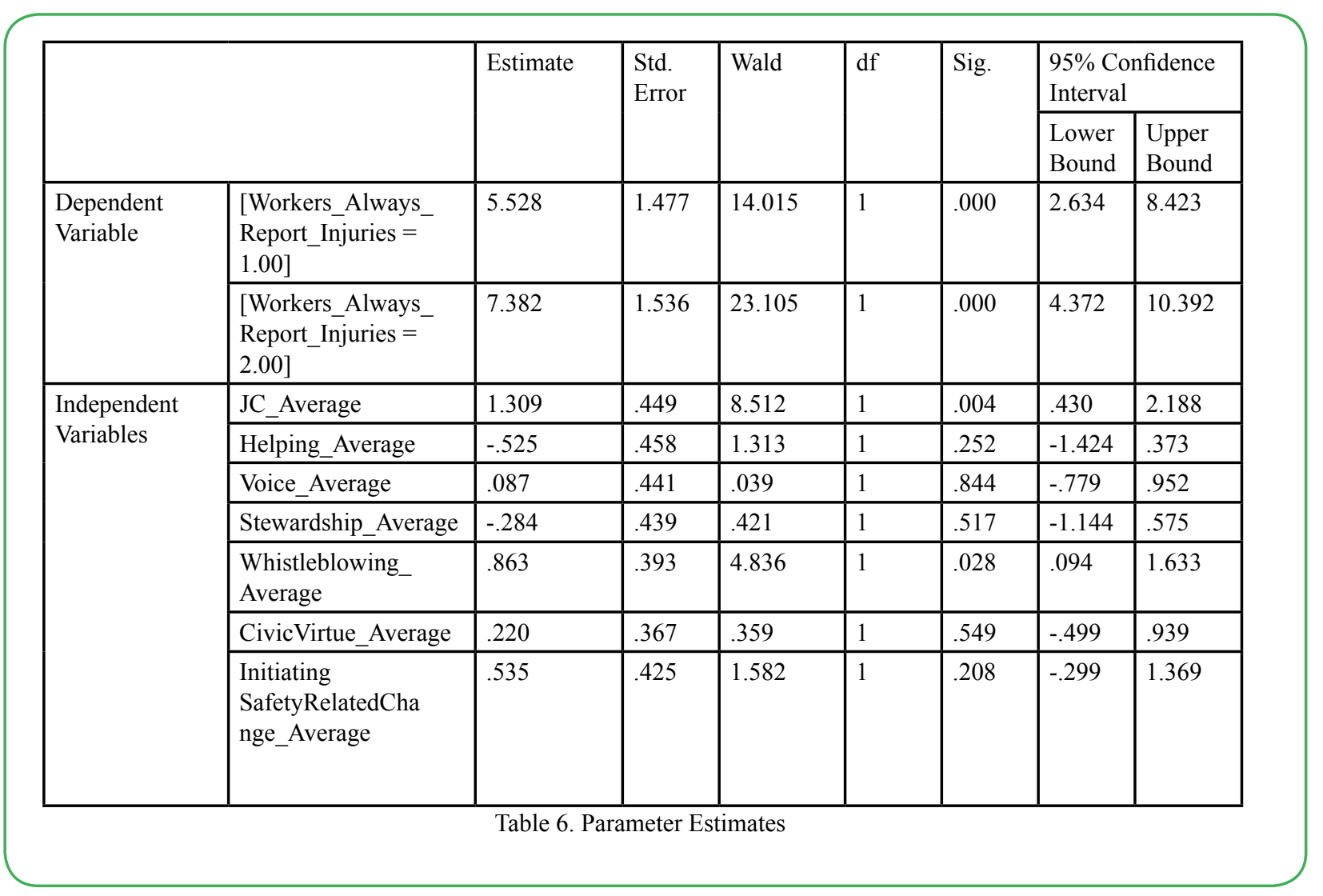


Table 6 provides the results of the Wald's Chi-squared test to test each independent variable. From this test, only job control $\left(\mathrm{X}^{2}=\right.$ 8.512, $\mathrm{df}=1, \mathrm{p}<0.05)$ and whistleblowing $\left(\mathrm{X}^{2}=4.836, \mathrm{df}=1, \mathrm{p}<\right.$ 0.05 ) showed significance in the model. While the Wald Chi-squared value is easy to calculate, its reliability is questionable. This can be contributed to larger samples having an inflated standard error. This would further result in lower Wald Chi-square scores [17].
A test of parallel lines was conducted to test the null hypothesis that the new model is valid when compared to the categories and subcategories. This test is sometimes referred to as parallelism. A 2 log-likelihood value was found for both a general model and the new model, which were then compared to find the chi-square value for the general model. These results can be seen in the table below.

\begin{tabular}{|l|l|l|l|l|}
\hline Model & $\begin{array}{l}\text {-2 Log } \\
\text { Likelihood }\end{array}$ & Chi-Square & df & Sig. \\
\hline $\begin{array}{l}\text { Null } \\
\text { Hypothesis }\end{array}$ & 247.695 & & & \\
\hline General & 239.489 & 8.205 & 7 & .315 \\
\hline \multicolumn{5}{|c|}{ Table 7. Test of Parallel Lines } \\
\hline
\end{tabular}

The null hypothesis states that the location parameters (slope coefficients) are the same across response categories.

As shown in Table 7, the test of parallel lines on the general model does not provide a statistically significant result $\left(\mathrm{X}^{2}=247.695\right.$ $-239.489=8.205, \mathrm{df}=7, \mathrm{p}>0.05)$. Due to this, the test fails to reject the null hypothesis. This supports the null hypothesis that the slope coefficient from the new model is the same across the response categories and subcategories.

In order to conduct an odd-ratio analysis as a two by two, the values obtained by the participants was divided in to categories. For the question, "Employees always report injuries they acquire at work", responses from participants were divided in to a Disagree/Neutral category and an Agree category. For the 34 questions relating to both Job Control and Safety Citizenship, a sum was taken of each participants responses then divided in to either a score of "Less than 102" or "102 and up". For the sum of Job Control and Safety Citizenship questions, the minimum value a participant could achieve was 34 (selecting 1 for all questions) and the maximum value a participant could achieve was 170 (selecting 5 for all questions). A value of 102 was selected for the division as this would represent a participant selecting a 3 (or neutral) for all questions.

\begin{tabular}{|l|l|l|l|}
\hline \multicolumn{2}{|l|}{ Risk Estimate on Job Control and Safety Citizenship Questions } \\
\hline & Value & \multicolumn{2}{l|}{$95 \%$ Confidence Interval } \\
\cline { 3 - 5 } & & Lower & Upper \\
\hline $\begin{array}{l}\text { Odds Ratio for JC and SC (Less than } \\
102 / 102 \text { and up) }\end{array}$ & 3.491 & 1.164 & 10.470 \\
\hline $\begin{array}{l}\text { Employees always report injuries they } \\
\text { acquire at work = Disagree/Neutral }\end{array}$ & 1.733 & 1.199 & 2.504 \\
\hline $\begin{array}{l}\text { Employees always report injuries they } \\
\text { acquire at work = Agree }\end{array}$ & .496 & .235 & 1.050 \\
\hline N of Valid Cases & 152 & & \\
\hline
\end{tabular}

Table 8 . Risk estimate on job control and safety citizenship questions.

Ttable 8 shows that a participant that scored less than 102 on Job Control and Safety Citizenship questions are 3.491 times more likely to respond they either disagree or are neutral to the question "Employees always report injuries they acquire at work".

\section{Conclusion}

The purpose of this study was to assess the relationship between the behavior of reporting occupational injuries, self-reported job control, and six safety citizenship scores (i.e. stewardship $\left[\mathrm{IV}_{2}\right]$, civic virtue $\left[\mathrm{IV}_{3}\right]$, whistleblowing $\left[\mathrm{IV}_{4}\right]$, initiating safety-related change $\left[\mathrm{IV}_{5}\right]$, voice $\left[\mathrm{IV}_{6}\right]$, and helping $\left[\mathrm{IV}_{7}\right]$ ) from two companies in the Midwestern region of the United States. From the results, it was found that whistleblowing $\left[\mathrm{IV}_{4}\right]$ and self-reported job control predicted whether or not a worker would report an injury. The findings of this study are not surprising, as affiliative safety citizenship tends to focus on promoting socialization of positive safety culture and ensuring current levels of safety performance and compliance are maintained $[7,11]$. Employees who deem safety as part of their work tasks are more likely to have evolved definitions of safety citizenship roles. An employee's desire to reduce workplace injuries, illnesses, and fatalities will cultivate safety behaviors such as reporting occupational injuries, workplace safety violations, and hazards [12]. Such protective behaviors are considered avoidance in nature (i.e. avoid the negative impact of injuries, illnesses, and fatalities on a workplace) and are associated with two safety citizenship sub-dimensions of action (i.e. stewardship and whistleblowing) [18]. Employees who engage in affiliative safety citizenship behaviors often possess the needed safety knowledge to move from a state of safety motivation to safety participation [14]. Such movement illustrates that the employee cares about the health, safety, and well-being of their coworkers $[15,19]$.

Important to note is the difference in safety performance outcomes between prosocial and proactive safety behaviors. The findings of this study support prior research focusing on the predictability of noninjury workplace incidents and micro-accidents through increases in prosocial behaviors. As expected, the significant sub-dimension of action associated with self-reported workplace incidents was whistleblowing, which is a prosocial behavior [12]. Whistleblowing refers to an employee's ability to monitor their colleagues for safe work performance, report safety violations to management, and 
demonstrate how to follow safe working procedures. The increase in the behavior of reporting occupational injuries would be expected, as an individual with a higher whistleblowing score would be cognizant of at-risk situations in the workplace and stop their coworkers from engaging in at-risk behaviors.

The addition of job control as statistically significant variable in determining if employees will report an occupational injury is not surprising. Synder and colleagues [16] note that employees with more job control will feel empowered to prevent and report injuries. Overall, employees with increased job control have increased safety citizenship, a positive perception of a workplace's safety climate and management's commitment to safety [3]. When employees perceive they work for a management team who prioritizes the safety of its employees, they are more likely to engage in affiliative safety citizenship. Affiliative safety citizenship is prosocial in nature, meaning, employees engaged in affiliative safety citizenship aim to please their management team, maintain positive safety climate and safety status quo[7]. Employees who feel they have more time or job control to participate in safety activities will do so.

\section{Practical Implications}

Increasing the behavior of reporting occupational injuries requires management to increase the intrinsic safety motivation of their employees [20]. Motivated employees are eager to gain needed safety knowledge to be proactive in their safety approach. A climate of teamwork and camaraderie can increase the proactive nature of employees. Such a climate is built through establishing employee commitment, which is gained through promotion of prosocial behaviors; however, prosocial behaviors alone will not promote the behavior of reporting occupational injuries and thus, preventing lost-time workplace incidents. Workplace safety performance is significantly impacted by proactive safety participation [21]. Management should target their safety campaigns based upon the desired safety performance outcome (i.e. reduction in microaccidents, non-injury occupational incidents, lost-time workplace injuries, and near misses).

Promoting affiliative safety citizenship, which is comprised of prosocial sub-dimensions of action, will lead to decreased rates of micro-accidents and non-injury workplace incidents [12]. When attempting to reduce lost-time workplace injuries and near-misses, safety leaders should place emphasis on challenge safety citizenship, which is comprised of proactive sub-dimensions of action, and depends on employees voicing their safety concerns and initiating safety change. Job control plays a key role in bolstering prosocial and proactive safety behaviors. Employees with more job control exhibit increased safety citizenship and decreased likelihood of involvement in micro-accidents and lost-time occupational injuries [16]. Further, employees with increased job control have positive perspectives of management's commitment to safety [3]. These positive perceptions may be linked to perceived organizational support, which in turn increases employee commitment to reporting occupational injuries [22]. Increasing prosocial and proactive safety behaviors requires management to implement 'signaling' activities that emphasize the workplace's support of employees. Such activities may include improving workplace conditions, enabling desired safety behaviors, and training. For example, proactive 'signaling' activities may include communication initiatives that not only promote desired safety behaviors but also have a built-in rewards system for proactive behaviors [12].

\section{Limitations \& Future Research}

A few limitations are noted for this study. First, due to the crosssectional approach of this study the results only represent employee perceptions for a single point in time. Therefore, it is recommended that a longitudinal approach be employed to provide a more accurate representation of employee self-reported job control and safety citizenship. In addition, , because a survey instrument was used in this study, there will be inherent biases prevalent within the results. Recall bias, acquiescence bias, and other biases such as these could have affected the results. Although safety surveys are limiting, they are an incredibly useful tool in determining various aspects of safety climate within a given workplace.

Conflict of Interest: The authors report no conflict of interest.

\section{References}

1. Hofmann, D.A., Burke, M.J., \& Zohar, D., (2017). 100 years of occupational safety research: from basic protections and work analysis to a multilevel view of workplace safety and risk. Journal of Applied Psychology, 102 (3), 375-388.

2. Bureu of Labor Statistics. (2020). Injuries, illnesses, and fatalities. Retrieved from https://www.bls.gov/iif/.

3. Pinion, C., Brewer, S., Douphrate, D., Whitehead, L., Dellifraine, J., Taylor, W.C., \& Klyza, P.J. (2017). The impact of job control on employee perception of management commitment to safety. Safety Science 93: 70-75.

4. Neal, A., M.A. Griffin, \& P.M. Hart. (2000). The impact of organizational climate on safety climate and individual behavior. Safety Science, 34: 99-109.

5. Pinion, C., Klyza, J., Brewer, S., \& Douphrate, D. (2018). North American engineering, procurement, fabrication, and construction worker safety climate perception affected by job position. Safety 4(14) 1-11.

6. Didla, S., Mearns, K., \& Flin, R. (2009). Safety citizenship behavior: a proactive approach to risk management. Journal of Risk Research, 12, 475-483.

7. Curcuruto, M., Conchie, S., \& Griffin, M., (2019). Safety citizenship behavior (SCB) in the workplace: A stable construct? Analysis of psychometric invariance across four European countries, Accident Analysis and Prevention, 129, 190-201.

8. Hofmann, D.A., Morgeson, F.P., \& Gerras, S.J., (2003). Climate as a moderator of the relationship between leader-member exchange and content specific citizenship: Safety climate as an exemplar. Journal of Applied Psychology, 88, 170-178.

9. Braun, V., and Clarke, V. (2006) Using thematic analysis in psychology. Qualitative Research in Psychology, 3 (2). pp. 77-101. ISSN ,1478-0887 Available from: http://eprints.uwe. ac.uk/1173

10. Neal, A., \& Griffin, M.A. (2006). A study of the lagged relationships among safety climate, safety motivation, safety behavior, and incidents at the individual and group levels. Journal of Applied Psychology, 91, 946-953.

11. Stoverink, A.C., Chiaburu, D.S., Li, N., \& Zheng, X. (2018). Supporting team citizenship: The influence of team social resources on team-level affiliation-oriented and challengeoriented behavior. Human Resource Management Journal, 28, 201-215

12. Curcuruto, M., Conchie, S., Mariani, M., \& Violante, F. (2015). The role of prosocial and proactive safety behaviors in predicting safety performance. Safety Science, 80: 317-323.

13. Hofmann, D.A. \& Morgeson, F.P. (1999). Safety-related behavior as a social exchange: The role of perceived organizational support and leader-member exchange. Journal of Applied Psychology, 84, 286-296.

14. Chmiel, N., Laurent, J., \& Hansez, I. (2017). Employee perspectives on safety citizenship behaviors and safety violations, Safety Science, 93, 96-107.

15. Turner, N., Stride, C., Carter, A., McCaughey, D., \& Carroll, A., (2012). Job demands control-support model and employee safety performance. Accident Analysis \& Prevention, 45, 81817. 
16. Snyder, L., Krauss, A., Chen, P., Finlinson, S., \& Huang, Y., (2008). Occupational safety: Application of the job demandcontrol-support model. Accident Analysis \& Prevention, 40, 1713-1723.

17. Bewick, V., Cheek, L., \& Ball, J. (2005). Statistics review 14: Logistic regression. In Critical Care (Vol. 9, Issue 1, pp. 112 118). BioMed Central. https://doi.org/10.1186/cc3045

18. Curcuruto, M. \& Griffin, M. (2016). Safety climate in organizations. Annual Review of Organizational Psychology and Organizational Behavior, 3, 191-212.

19. Curcuruto, M. \& Grififn, M. (2018). Prosocial and proactive safety citizenship behavior: The mediating role of affective commitment and psychological ownership. Safety Science, 104, 29-38.
20. Conchie, S.M., (2013).Transformational leadership, intrinsic motivation, and trust: a moderated-mediated model of workplace safety. J Occup Health Psychol, 18(2):198-210. doi: 10.1037/a0031805.

21. Christian, M., Bradley J., Walalce, J., \& Burke M., (2009). Workplace safety: A meta-analysis of the roles of person and situation factors. Journal of Applied Psychology, 94, 1103-1127.

22. Reader, T.W., Mearns, K., Lopes, C., \& Kuha, J. (2017) Organizational support for the workforce and employee safety citizenship behaviors: A social exchange relationship. Human Relations, 70(3), 362-385. 